\title{
Remembering Jerry Lwanga: A Perspective from His Colleagues
}

Tony L. Goldberg ${ }^{1}$ - Samuel Angedakin ${ }^{2}$ - Gilbert M. Isabirye Basuta ${ }^{3}$. Michelle Brown $^{4}$. Thomas M. Butynski ${ }^{5}$. Colin A. Chapman ${ }^{6}$. Lauren Chapman $^{7} \cdot$ Sholly Gunter $^{8}$. Innocent Kato ${ }^{9} \cdot$ Jean-Michel Krief $^{10}$. Sabrina Krief ${ }^{10,11}$. Joanna E. Lambert ${ }^{12}$ - Kevin E. Langergraber ${ }^{13}$. John C. Mitani ${ }^{14}$ - Martin N. Muller ${ }^{15}$. Sherry V. Nelson ${ }^{15} \cdot$ Patrick Omeja $^{9}$. Emily Otali ${ }^{9} \cdot$ Kevin B. Potts $^{16} \cdot$ Elizabeth A. Ross $^{17} \cdot$ Jessica M. Rothman $^{18}$. Carolyn Rowney ${ }^{19}$. Eric Sande ${ }^{3}$. Thomas T. Struhsaker ${ }^{20}$. Dennis Twinomugisha ${ }^{9}$. David P. Watts ${ }^{21}$. Geoffrey Weny ${ }^{9}$. Richard W. Wrangham ${ }^{22}$

The untimely death of Dr. Jeremiah Lwanga has cast a pall over the research community of Kibale National Park, Uganda. Jerry was Director of the Makerere University Biological Field Station (MUBFS) in Kibale, and a mentor, role model, and friend to staff, students and colleagues. During the final months of his life, Jerry battled an enigmatic illness before succumbing on August 31, 2015.

Tony L. Goldberg

tony.goldberg@wisc.edu

1 School of Veterinary Medicine and Global Health Institute, University of Wisconsin-Madison, Madison, Wisconsin, USA

2 Ngogo Chimpanzee Project, Kibale National Park, Uganda

3 Department of Biological Sciences, Makerere University, Kampala, Uganda

4 Department of Anthropology, University of California, Santa Barbara, Santa Barbara, California, USA

5 Lolldaiga Hills Research Programme, Sustainability Centre Eastern Africa, Nanyuki, Kenya

6 Department of Anthropology and School of Environment, McGill University, Montreal, QC, Canada

7 Department of Biology, McGill University, Montreal, QC, Canada

8 Department of Biology, McLennnan Community College, Waco, Texas, USA

9 Makerere University Biological Field Station, Fort Portal, Uganda

10 Sebitoli Chimpanzee Project, Fort Portal, Uganda 
Jerry's death hits close to home. Like us, Jerry had a passion for nature, and this underpinned his career in research and conservation. Jerry's studies of forest ecology and primatology continued a long tradition that helped establish and maintain Kibale as a premier field site. When Jerry was asked to take the position of Director of MUBFS, he accepted out of a sense of duty and the academic's all-too-familiar inability to say "no," but he followed through with dedication and enthusiasm. We recall meeting Jerry at the MUBFS offices or at Makerere University's main campus in Kampala. The conversations usually evolved into friendly gossip about people, politics and science. Jerry's world was our world.

As Director, Jerry transformed MUBFS. Its ailing infrastructure began to show new signs of life soon after he took charge. The forest trail system improved, the roads got smoother, the plumbing started working again, the grass around the buildings no longer grew neck-high, and the staff were reinvigorated with a sense of pride in the station. Word got out. Growing numbers of students, researchers and field courses began to visit MUBFS. The station edged towards financial stability for the first time in a long time. With an eye towards the future, Jerry helped coordinate several important improvement and construction projects, the most recent of which was a new herbarium. The structure is complete, but it lies empty, and its fate is now uncertain.

We often found Jerry at his desk, hidden behind reams of paperwork and harried by constant interruptions of staff, students, and (yes) colleagues. It was no secret, though, that Jerry really longed to be in the forest. When Jerry visited Ngogo, a field site in the middle of Kibale where he maintained a research program, he much preferred to walk the $15 \mathrm{~km}$ than to drive. It's a beautiful walk, up and down hills, through forest and grassland, and with a good chance of seeing elephant or buffalo in the clearings, preferably at a distance. Jerry found solace during these hikes; he regularly visited Ngogo not only to continue his work there, but also as a respite from the ever-mounting responsibilities he shouldered.

Jerry's was not an ebullient personality. Rather, he was a quiet, thoughtful, considerate and unassuming man. He was the type to get privately frustrated rather than angry, and to celebrate his successes with a self-effacing smile. He had also refined the classic

\footnotetext{
11 Muséum National d'Histoire Naturelle, Paris, France

12 Department of Anthropology, University of Colorado, Boulder, Colorado, USA

13 School of Human Evolution \& Social Change, Arizona State University, Tempe, Arizona, USA

14 Department of Anthropology, University of Michigan, Ann Arbor, Michigan, USA

15 Department of Anthropology, University of New Mexico, Albuquerque, New Mexico, USA

16 Department of Biology, Augsburg College, Minneapolis, Minnesota, USA

17 The Kasiisi Project, Cambridge, Massachusetts, USA

18 Department of Anthropology, Hunter College, New York City, New York, USA

19 Department of Primatology, Max Planck Institute for Evolutionary Anthropology, Leipzig, Germany

20 Department of Evolutionary Anthropology, Duke University, Durham, North Carolina, USA

21 Department of Anthropology, Yale University, New Haven, Connecticut, USA

22 Department of Human Evolutionary Biology, Harvard University, Cambridge, Massachusetts, USA
} 
administrator's skill of being somewhere else when things were going well but suddenly appearing at just the right moment if things started to go awry. Like all of us, Jerry strove for that elusive "life-work balance." Jerry dearly loved and supported his extended family, and his children inherited his appreciation for the value of education and research (his youngest son is currently a Ph.D. student in biochemistry at Washington University in the USA). He is survived by his wife Agnes Bukirwa, his children Sam Wasswa, Sarah Nakato, Martin Lukwago, Eva Nanyunja, Ana Nassali and George Katumba, and his adopted nephews and nieces Rhoda Namuddu, Donald Kafeero, and Shannon Kabugo. He also worked passionately to build and support Kakiri Junior School near his hometown, which he founded with his own resources (the school motto, "Ogutateganya," is the stem of a Luganda proverb translating roughly as "There is no gain without pain").

There is a lot of talk these days about "capacity building" in Sub-Saharan Africa. This is the idea that Africans and their institutions need "propping up" by nations with deeper pockets and more advanced technical expertise. Although Jerry certainly benefitted from the collaboration and support of colleagues from abroad, he built his own capacity. He became an excellent scientist as a result of his own resourcefulness and ambition. He became a successful Director because he rose to the task; if he hadn't, someone else might have, but probably not as well, and Jerry knew that. He transformed MUBFS because it was the right thing to do - for him, for us, for Kibale, for Makerere, for Uganda, and for science.

Now, as we reflect on Jerry's life, we have begun to grasp how much we've lost. Yes, we've lost a fine scientist and administrator who represented the best of Uganda and was an example for the rest of Africa. But we've also lost a genuine friend. None of us will see Kibale or our relationship to it in quite the same way again. We will all mourn as we walk the leaf-strewn trails, listen to the cacophony of insects and birds, wonder at the butterflies, gaze in awe at the towering trees and verdant understory, watch the primates or glimpse the occasional duiker, and reflect upon Jerry's abridged life and tragically premature legacy.

Dr. Jeremiah Ssali Lwanga (1960 - 2015). Photo credit: Sholly Gunter.

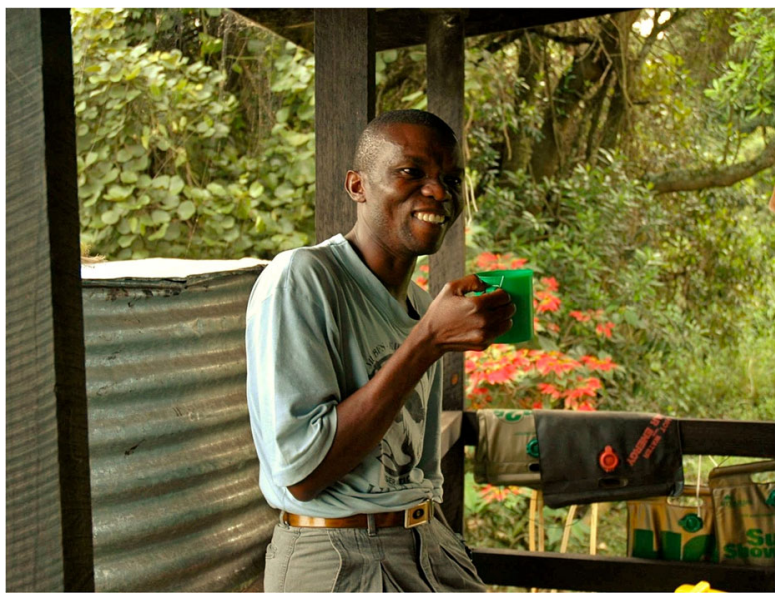


Acknowledgments We acknowledge that Jerry Lwanga touched the lives of many more people than are included here as co-authors.

\section{Jerry Lwanga's Bibliography}

Angedakin, S., \& Lwanga, J. S. (2011). Changes in group size and composition of the blue monkeys (Cercopithecus mitis stuhlmanni) between 1984 and 2009 at Ngogo, Kibale National Park, Uganda. African Journal of Ecology, 49(3), 362-366.

Box, H., Butynski, T. M., Chapman, C. A., Lwanga, J. S., Oates, J. F., Olupot, W., Rudran, R., \& Waser, P. M. (2008). Thomas T. Struhsaker: recipient of the lifetime achievement award of the International Primatological Society 2006. International Journal of Primatology, 29(1), 13-18.

Emery Thompson, M., Muller, M. N., Wrangham, R. W., Lwanga, J. S., \& Potts, K. B. (2009). Urinary Cpeptide tracks seasonal and individual variation in energy balance in wild chimpanzees. Hormones and Behavior, 55(2), 299-305.

Heimonen, K., Lwanga, J. S., Mutanen, M., Nyman, T., \& Roininen, H. (2013). Spatial and temporal variation in community composition of herbivorous insects on Neoboutonia macrocalyx in a primary tropical rain forest. Journal of Tropical Ecology, 29(3), 229-241.

Howard, P. C., Davenport, T. R. B., Kigenyi, F. W., Viskanic, P., Baltzer, M. C., Dickinson, C. J., Lwanga, J. S., Matthews, R. A., \& Mupada, E. (2000). Protected area planning in the tropics: Uganda's national system of forest nature reserves. Conservation Biology, 14(3), 858-875.

Howard, P. C., Viskanic, P., Davenport, T. R. B., Kigenyi, F. W., Baltzer, M. C., Dickinson, C. J., Lwanga, J. S., Matthews, R. A., \& Balmford, A. (1998). Complementarity and the use of indicator groups for reserve selection in Uganda. Nature, 394(6692), 472-475.

Isabirye-Basuta, G. M., \& Lwanga, J. S. (2008). Primate populations and their interactions with changing habitats. International Journal of Primatology, 29(1), 35-48.

Laurance, W. F., et al. (2012). Averting biodiversity collapse in tropical forest protected areas. Nature, 489(7415), 290-294.

Lwanga, J. S. (1994). The role of seed and seedling predators and browsers on the regeneration of two forest canopy species (Mimusops bagshawei and Strombosia scheffleri) in Kibale forest reserve, Uganda. Ph.D. Thesis. Gainesville, Florida: University of Florida.

Lwanga, J. S. (2003a). Forest succession in Kibale National Park, Uganda: implications for forest restoration and management. African Journal of Ecology, 41(1), 9-22.

Lwanga, J. S. (2003b). Localized tree mortality following the drought of 1999 at Ngogo, Kibale National Park, Uganda. African Journal of Ecology, 41(2), 194-196.

Lwanga, J. S. (2006a). The influence of forest variation and possible effects of poaching on duiker abundance at Ngogo, Kibale National Park, Uganda. African Journal of Ecology, 44(2), 209-218.

Lwanga, J. S. (2006b). Spatial distribution of primates in a mosaic of colonizing and old growth forest at Ngogo, Kibale National Park, Uganda. Primates, 47(3), 230-238.

Lwanga, J. S., Balmford, A., \& Badaza, R. (1998). Assessing fern diversity: relative species richness and its environmental correlates in Uganda. Biodiversity and Conservation, 7(11), 1387-1398.

Lwanga, J. S., Butynski, T. M., \& Struhsaker, T. T. (2000). Tree population dynamics in Kibale National Park, Uganda 1975-1998. African Journal of Ecology, 38(3), 238-247.

Lwanga, J. S., \& Isabirye-Basuta, G. M. (2008). Long-term perspectives on forest conservation: lessons from research in Kibale National Park. In R. W. Wrangham \& E. A. Ross (Eds.), Science and conservation in African forests: the benefits of long term research (pp. 63-74). Cambridge: Cambridge University Press.

Lwanga, J. S., Struhsaker, T. T., Struhsaker, P. J., Butynski, T. M., \& Mitani, J. C. (2012). Primate population dynamics over 32.9 years at Ngogo, Kibale National Park, Uganda. American Journal of Primatology, 73(10), 997-1011.

Mitani, J. C., Sanders, W. J., Lwanga, J. S., \& Windfelder, T. L. (2001). Predatory behavior of crowned hawkeagles (Stephanoaetus coronatus) in Kibale National Park, Uganda. Behavioral Ecology and Sociobiology, 49(2-3), 187-195.

Mitani, J. C., Struhsaker, P. J., \& Lwanga, J. S. (2000). Primate community dynamics in old growth forest over 23.5 years at Ngogo, Kibale National Park, Uganda: implications for conservation and census methods. International Journal of Primatology, 21(2), 269-286. 
Mitani, J. C., Watts, D. P., \& Lwanga, J. S. (2002). Ecological and social correlates of chimpanzee party size. In C. Boesch, G. Hohmann, \& L. Marchant (Eds.), Behavioural diversity in chimpanzees and bonobos (pp. 102-111). Cambridge: Cambridge University Press.

Okiror, P., Chono, J., Nyamukuru, A., Lwanga, J. S., Sasira, P., \& Diogo, P. (2012). Variation in woody species abundance and distribution in and around Kibale National Park, Uganda. ISRN Forestry, 490461, $1-9$.

Omeja, P. A., Chapman, C. A., Obua, J., Lwanga, J. S., Jacob, A. L., Wanyama, F., \& Mugenyi, R. (2011a). Intensive tree planting facilitates tropical forest biodiversity and biomass accumulation in Kibale National Park, Uganda. Forest Ecology and Management, 261(3), 703-709.

Omeja, P. A., Jacob, A. L., Lawes, M. J., Lwanga, J. S., Rothman, J. M., Tumwesigye, C., \& Chapman, C. A. (2014). Changes in elephant abundance affect forest composition or regeneration? Biotropica, 46(6), 704 711.

Omeja, P. A., Lwanga, J. S., Obua, J., \& Chapman, C. A. (2011b). Fire control as a simple means of promoting tropical forest restoration. Tropical Conservation Science, 4(3), 287-299.

Potts, K. B., Chapman, C. A., \& Lwanga, J. S. (2009). Floristic heterogeneity between forested sites in Kibale National Park, Uganda: insights into the fine-scale determinants of density in a large-bodied frugivorous primate. Journal of Animal Ecology, 78(6), 1269-1277.

Potts, K. B., \& Lwanga, J. S. (2014). Floristic heterogeneity at Ngogo, Kibale National Park, Uganda and possible implications for habitat use by chimpanzees (Pan troglodytes). African Journal of Ecology, 52(4), 427-437.

Santiago, M. L., Lukasik, M., Kamenya, S., Li, Y., Bibollet-Ruche, F., Bailes, E., Muller, M. N., Emery, M., Goldenberg, D. A., Lwanga, J. S., Ayouba, A., Nerrienet, E., McClure, H. M., Heeney, J. L., Watts, D. P., Pusey, A. E., Collins, D. A., Wrangham, R. W., Goodall, J., Brookfield, J. F., Sharp, P. M., Shaw, G. M., \& Hahn, B. H. (2003). Foci of endemic simian immunodeficiency virus infection in wild-living eastern chimpanzees (Pan troglodytes schweinfurthii). Journal of Virology, 77(13), 7545-7562.

Struhsaker, T. T., Butynski, T. M., \& Lwanga, J. S. (1988). Hybridization between redtail (Cercopithecus ascanius schmidti) and blue (C. mitis stuhlmanni) monkeys in the Kibale Forest, Uganda. In A. GautierHion, F. Bourliere, J. P. Gautier, \& J. Kingdon (Eds.), A primate radiation: evolutionary biology of the African Guenons (pp. 477-497). New York: Cambridge University Press.

Struhsaker, T. T., Lwanga, J. S., \& Kasenene, J. M. (1996). Elephants, selective logging and forest regeneration in Kibale Forest, Uganda. Journal of Tropical Ecology, 12(1), 45-64.

Watts, D. P., Potts, K. B., Lwanga, J. S., \& Mitani, J. C. (2012a). Diet of chimpanzees (Pan troglodytes schweinfurthii) at Ngogo, Kibale National Park, Uganda, 1. diet composition and diversity. American Journal of Primatology, 74(2), 114-129.

Watts, D. P., Potts, K. B., Lwanga, J. S., \& Mitani, J. C. (2012b). Diet of chimpanzees (Pan troglodytes schweinfurthii) at Ngogo, Kibale National Park, Uganda, 2. Temporal variation and fallback Foods. American Journal of Primatology, 74(2), 130-144.

Windfelder, T. L., \& Lwanga, J. S. (2002). Group fission in red-tailed monkeys (Cercopithecus ascanius) in Kibale National Park, Uganda. In M. E. Glenn \& M. Cords (Eds.), The guenons: diversity and adaptation in African monkeys (pp. 147-159). New York: Kluwer Academic/Plenum Publishers. 